
VOLUME 10 NOMOR 6 DESEMBER 2021

ISSN : 2303-1514 | E-ISSN : 2598-5949

\title{
UPAYA KEPALA SEKOLAH MELALUI SUPERVISI DALAM MENINGKATKAN KREATIVITAS GURU DALAM PEMBELAJARAN DARING DI SDN O22 HARAPAN BARU
}

\author{
Sahippuddin
}

SDN 022 Harapan Baru Kecamatan Kempas, Indragiri Hilir, Riau, Indonesia sahippuddin397@gmail.com

\section{THE PRINCIPAL'S EFFORTS TO IMPROVE TEACHERS' CREATIVITY IN ONLINE LEARNING AT SDN O22 HARAPAN BARU}

\begin{tabular}{|c|c|}
\hline ARTICLE HISTORY & ABSTRACT \\
\hline $\begin{array}{l}\text { Submitted: } \\
12 \text { Oktober } 2021 \\
12^{\text {th }} \text { October } 2021\end{array}$ & $\begin{array}{l}\text { Abstract: This study aimed to increase teachers' creativity in the learning process through the } \\
\text { efforts made by the school principal in online learning. The form of this research was school } \\
\text { action research conducted by the principal himself, using quantitative descriptive methods. The } \\
\text { place of the study was SDN } 022 \text { Harapan Baru, Kecamatan Kempas, with the research subjects } \\
\text { being the teachers. The results of this study were the principal's efforts in increasing teachers' } \\
\text { creativity in teaching through academic supervision were successful, as evidenced by the } \\
\text { research data. First, the teacher's creativity in preparing lesson plans got an average score of } \\
75 \text { with a percentage of } 85 \% \text {, in the good category. Second, the item created using the learning } \\
\text { method obtained an average value of } 80 \text { with a percentage of } 90 \% \text { in the good category. The } \\
\text { online learning management initiative item obtained an average value of } 70 \text { with a percentage } \\
\text { of } 80 \% \text { in the good category. The student learning outcomes items obtained an average of } 70 \\
\text { with a percentage of } 80 \% \text { in the good category. It can be concluded that the efforts made by the } \\
\text { principal were successful in increasing the creativity of teachers in the learning process at } \\
\text { SDN } 022 \text { Kempas District, Indragiri Hilir Regency. }\end{array}$ \\
\hline & keywords: teacher's creativity, the principal's efforts \\
\hline
\end{tabular}

Accepted:

14 November 2021

$14^{\text {th }}$ November 2021

Published:

27 Desember 2021

$27^{\text {th }}$ December 2021
Abstrak: penelitian ini bertujuan untuk meningkatkan kreativitas guru dalam proses pembelajaran, dengan upaya yang dilakukan oleh kepala sekolah pada era pembelajaran daring. Bentuk penelitian ini berupa penelitian tindakan sekolah yang dilakukan oleh kepala sekolah itu sendiri, dengan menggunakan metode deskriptif kuantitatif. Tempat penelitian yaitu dilakukan di SDN 022 Harapan Baru Kecamatan Kempas dengan subjek penelitian adalah guru-guru yang mengajar. Hasil penelitian ini adalah upaya kepala sekolah dalam meningkatkan kreativitas guru dalam mengajar melalui supervise akademik dapat dikatakan berhasil, terbukti dari data hasil penelitian yaitu Pada item kreativitas guru dalam menyusun RPP didapat nilai rata-rata sebesar 75 dengan persentase $85 \%$ pada kategori baik, pada item kreativitas menggunakan metode pembelajaran didapat nilai rata-rata sebesar 80 dengan persentase $90 \%$ pada kategori baik, kemudian pada item inisiatif pengelolaan pembelajaran daring didapat nilai rata-rata sebesar 70 dengan persentase sebesar $80 \%$ pada kategori baik, dan pada item hasil belajar siswa didapat rata-rata sebesar 70 dengan persentase $80 \%$ pada kategori baik. Dapat disimpulkan bahwa upaya yang dilakukan oleh kepala sekolah berhasil dalam meningkatkan kreativitas guru dalam proses pembelajaran di SDN 022 Kecamatan Kempas Kabupaten Indragiri Hilir.

Kata Kunci: kreativitas guru, upaya kepala sekolah

\section{CITATION}

Sahippuddin, S. (2021). Upaya Kepala Sekolah Melalui Supervisi Dalam Meningkatkan Kreativitas Guru Dalam Pembelajaran Daring Di SDN 022 Harapan Baru. Primary: Jurnal Pendidikan Guru Sekolah Dasar, 10 (6), 1547-1553. DOI: http://dx.doi.org/10.33578/jpfkip.v10i6.8607. 


\section{PENDAHULUAN}

Pendidikan memiliki peran yang penting dan sangat berpengaruh dalam membangun serta melatih kemampuan seseorang sebagai upaya menjawab persaingan dan perubahan kondisi dalam segala bidang kehidupan. Menurut Purwanto (2007) pendidikan dapat dijadikan sebagai sarana mendewasakan siswa dalam berbagai aspek kehidupan yang menyangkut ranah ideologi, ekonomi, politik, sosial, dan budaya. Salah satu penggerak di sekolah yang memiliki peran strategis dalam pengelolaan adalah kepada sekolah, sehingga kepala sekolah harus memiliki kemampuan manajemen yang baik(Sabirin, 2012). Kepala Sekolah disyaratkan mampu menyusun perencanaan yang bersifat rutin dalam berbagai bidang yang terkait dengan proses pendidikan di sekolah. Manajemen yang baik akan menentukan keberhasilan dalam merealisasikan visi, misi dan tujuan sekolah.

Menurut Slamet (2000) Sekolah dapat berjalan dengan baik dan efektif apabila pelaku/penggerak memiliki kemampuan atau kompetensi dalam pengelolaannya. Guru yang berkualitas, memiliki kemampuan multi dimensi dan multi situasi sangat dibutuhkan untuk suksesnya proses belajar mengajar di sekolah. Kualitas guru sangat dipengaruhi oleh sistem manajemen kepala sekolah yang diterapkan di sekolah tersebut. Termasuk di dalamnya adalah bagaimana upaya kepala sekolah dalam mengoptimalkan peran guru dengan baik sehingga mampu memberikan dapak positif untuk menjaga kualitas baik secara akademik maupun non akademik. Guru adalah sosok manusia yang harus digugu dan ditiru. Sebagai salah satu unsur dalam penyelenggaraan sistem pendidikan di sekolah, guru memiliki peran teramat penting dalam membentuk, membina serta mencapai hasil pendidikan (Barinto, 2012). Peran tersebut tentu akan sangat terasa apabila sosok guru mengajar di daerah atau desa-desa yang jauh dari hingar bingar kegiatan manusia seperti kota. Peran guru kerap sekali menjadi sumber inti dalam mentransformasi nilai-nilai ilmu pengetahuan maupun nilai-nilai lainnya kepada anak didik sehingga kemampuan, pengetahuan dan ketrampilan yang dimiliki guru mendominasi proses pembelajaran dan pembentukan hasil belajar terhadap anak didiknya (Suprihatiningrum, 2016).

Mewabahnya virus Corona (Covid-19) di Indonesia berimbas pada penghentian proses pembelajaran sistem tatap muka (luring), sedikit banyak akan mengakibatkan penurunan kualitas pembelajaran. Pada situasi seperti ini dibutuhkan langkah strategis dari sekolah agar proses belajar mengajar tetap dapat terkondisikan. Sebuah situasi yang tidak pernah dibayangkan di dunia pendidikan. Dampak yang tidak kecil tersebut mengharuskan sistem pembelajaran yang selama ini berjalan dengan baik harus mengalami perubahan. Perubahan yang tidak biasa merupakan ujian bagi guru dalam proses belajar mengajar sehingga kompetensi atau kemampuan seorang guru dipertaruhkan sejauh mana seorang guru mampu untuk tetap memberikan pembelajaran. Kondisi ini menuntut seorang kepala sekolah agar mampu mengelola untuk mempertahankan kualitas guru dalam memberikan layanan pembelajaran. Kepala sekolah dalam sebuah struktur organisasi memiliki porsi tertinggi pada sebuah lembaga pendidikan atau sekolah. Sehingga kepala sekolah harus memiliki penguasaan manajerial dan menganalisa terhadap kondisi yang terjadi di sekolah yang dipimpinnya.

Berdasarkan hasil pengamatan peneliti di SDN $022 \mathrm{X}$, terlihat bahwa kualitas mengajar guru masih kurang baik, cara pengajaran guru yang kurang menunjukkan perubahan yang berarti, walaupun sudah sekian kali dilakukan pelatihan. Guru sering kali hanya menggunakan metode ceramah dalam pembelajaran dan jarang menggunakan media penunjang dalam pembelajaran. Apabila ingin menjadi guru yang efektif, guru dituntut 
untuk meningkatkan dominasinya dalam proses pengajaran dengan menitikberatkan pada makna belajar. Untuk itu, guru perlu mewujudkan perilaku pembelajaran yang kreatif dengan tidak lagi memandang peserta didik sebagai objek pembelajaran semata melainkan juga sebagai subjek pembelajaran (Pardamean, 2009). Dalam proses belajar dan mengajar, kreatifitas dalam pembelajaran merupakan bagian dari suatu sistem yang tak terpisahkan dengan terdidik dan pendidik. Menurut Rusman (2016) peranan kreatifitas guru tidak sekedar membantu proses belajar mengajar dengan mencakup satu aspek dalam diri manusia saja, akan tetapi mencakup apekaspek lainnya yaitu kognitif, psikomotorik dan afektif. Secara umum kreatifitas guru memiliki fungsi utama yaitu membantu menyelesaikan pekerjaannya dengan cepat dan efisien. Menurut Aqib (2009) adapun pentingnya kreativitas guru dalam pembelajaran antara lain: (1) Kreatifitas guru berguna dalam transfer informasi lebih utuh, (2) Kreatifitas guru berguna dalam merangsang siswa untuk lebih berpikir secara ilmiah dalam mengamati gejala masyarakat atau gejala alam yang menjadi objek kajian dalam belajar, (3) Produk kreatifitas guru akan merangsang kreatifitas siswa.

Berdasarkan dari fenomena yang terjadi, kepala Sekolah sebagai pemimpin di Sekolah harus mampu mengambil tindakan untuk memperbaiki serta meningkatkan berbagai aspek penunjang keberhasilan pendidikan terutama kreativitas guru yang dapat meliputi kinerja, kemampuan mengolah kelas, disiplin, dan lainnya. Untuk itu, kepala sekolah sangat berperan penting terhadap keberhasilan pembelajaran, kepala Sekolah perlu melakukan tindakan baik itu berupa pengawasan, pelatihan, maupun pembinaan terhadap guru yang mengajar di Sekolah tersebut, agar dapat meningkatkan kreativitas guru dalam proses pembelajaran.

\section{KAJIAN TEORI Kreativitas}

Kreativitas adalah hal yang sangat penting dalam kehidupan, melalui kreativitas guru akan didorong untuk mencoba berbagai metode dalam melaksanakan proses pembelajaran, namun bagi banyak orang, kreativitas tampaknya sulit untuk dikembangkan. Menjadi guru yang kreatif memang tidak mudah, hanya sebagian kecil dari guru yang sudah ada yang bisa menjadi guru yang kreatif. Suatu saat, seorang guru bisa membuat dirinya begitu kreatif dimata siswanya. Kinerja guru merupakan serangkaian hasil kerja yang dilaksanakan sesuai dengan tugas pokok dan fungsinya. Menurut Andika (2016) yang dimaksud kreativitas adalah kemampuan seseorang untuk menghasilkan produk baru atau ide-ide yang orisinil, wawasan, restrukturasi, penemuan atau benda seni yang diterima oleh para ahli sebagai suatu yang memiliki nilai ilmiah, estetika, sosial, atau teknologi. Kreativitas ditandai dengan adanya kegiatan menciptakan sesuatu yang sebelumnya tidak ada dan tidak lakukan oleh seseorang atau adanya kecenderungan untuk menciptakan sesuatu.

Upaya kepala sekolah dalam meningkatkan kreativitas guru dalam proses pembelajaran. Kepala sekolah melakukan pengawasan dan menegaskan aturan yang mengharuskan para guru melakukan evaluasi serta mengembangkan metode pembelajaran berdasarkan tujuan dari pembelajaran itu sendiri agar pembelajaran terlaksana dengan baik. Menurut Oktavia (2014) mengatakan bahwa upaya adalah usaha untuk menyampaikan maksud, akal dan ikhtiar. Sejalan dengan pendapat Husein (2017) mengatakan upaya adalah bagian yang dimainkan oleh guru atau bagian dari tugas yang harus dilaksanakan.Usaha yang dapat dilakukan kepala sekolah dalam meningkatkan kreativitas guru dalam pembelajaran yaitu : (1) Melalui pemberian supervisi, (2) Pemberian pembinaan dan pengembangan, (3) Pemberian reward bagi guru yang memiliki kreativitas yang tinggi, (4) Memagangkan guru, (5) Melakukan studi kasus, (6) Menciptakan 

VOLUME 10 NOMOR 6 DESEMBER 2021

ISSN : 2303-1514 | E-ISSN : 2598-5949

suasana kerja yang menyenangkan, (7) Memberi kebebasan (Sedarmayanti, 2010).

\section{METODE PENELITIAN}

Dalam penelitian ini, kepala Sekolah sekaligus peneliti melakukan penelitian dengan tujuan untuk meningkatkan kreativitas guru dalam kegietan pembelajaran guna mencapai keberhasilan pembelajaran tersebut. Bentuk penelitian berupa penelitian tindakan sekolah yang dilakukan di SDN 022 X Indragiri Hilir. Metode penelitian berupa kuantitatif deskriptif yang menjelaskan serta menggambarkan masalah yang sesuai dengan fakta-fakta yang ditemukan.

Tabel 1. Klasifikasi Pengukuran Persentase Hasil Observasi Aktivitas Guru

\begin{tabular}{ccc}
\hline No & Klasifikasi & Persentase $(\%)$ \\
\hline 1 & Baik & $67-100$ \\
2 & Cukup Baik & $34-66$ \\
3 & Kurang Baik & $0-33$ \\
\hline
\end{tabular}

(Arikunto, 2014).

Untuk analisis hasil belajar siswa melalui pemberian tes berupa ulangan harian menggunakan rumus sebagai berikut:

$$
p=\frac{\text { posrate }}{\text { baserate }} \times 100 \%
$$

(Zainal Aqib, 2009)

Keterangan:

$\mathrm{P} \quad=$ persentase peningkatan.

\section{Teknik Analisis Data}

Teknik analisis data observasi aktivitas guru dan siswa dalam penelitian ini menggunakan rumus sebagai berikut:

$$
p=\frac{\mathrm{f}}{\mathrm{n}} \times 100 \%
$$

(Anas Sudijono, 2004)

Keterangan:

$$
\begin{array}{ll}
\mathrm{f} & =\text { Frekuensi yang sedang dicari } \\
& \text { persentasenya } \\
\mathrm{n} & =\text { Number of Cases (jumlah } \\
& \text { frekuensi/banyaknya individu) } \\
\mathrm{P} & =\text { Angka persentase } \\
100 \% & =\text { Bilangan Tetap }
\end{array}
$$




\section{b. Hasil analisis kreativitas guru}

Salah satu upaya yang dilakukan oleh kepala sekolah dalam meningkatkan kreatifitas guru dalam pembelajaran pada penelitian ini yaitu dengan melakukan supervisi akademik terhadap guru, yang juga dapat berdampak pada hasil belajar atau nilai siswa. Berikut adalah data hasil analisis supervisi akademik kreativitas guru:

Tabel 3. Data analsisi kreativitas guru melalui supervisi

\begin{tabular}{lcc}
\hline \multicolumn{1}{c}{ Item } & Nilai rata-rata & Persentase indikator keberhasilan \\
\hline $\begin{array}{l}\text { Kreativitas dalam menyusun } \\
\text { RPP }\end{array}$ & 75 & $85 \%$ \\
$\begin{array}{l}\text { Kreativitas menggunakan } \\
\text { metode pembelajaran }\end{array}$ & 80 & $90 \%$ \\
$\begin{array}{l}\text { Inisiatif pengelolaan } \\
\text { pembelajaran daring }\end{array}$ & 70 & $80 \%$ \\
Hasil belajar siswa & 70 & $80 \%$ \\
\hline
\end{tabular}

Data hasil analisis kreativitas guru dapat dilihat pada tabel 3 diatas, dapat dilihat bahwa kreativitas guru mengalami peningkatan setelah dilakukannya refleksi pembelajaran oleh kepala sekolah berupa supervisi akademik. Pada item kreativitas guru dalam menyusun RPP didapat nilai rata-rata sebesar 75 dengan persentase $85 \%$ pada kategori baik, pada item kreativitas menggunakan metode pembelajaran didapat nilai rata-rata sebesar 80 dengan persentase $90 \%$ pada kategori baik, kemudian pada item inisiatif pengelolaan pembelajaran daring didapat nilai rata-rata sebesar 70 dengan persentase sebesar $80 \%$ pada kategori baik, dan pada item hasil belajar siswa didapat rata-rata sebesar 70 dengan persentase $80 \%$ pada kategori baik. Berdasarkan hasil penelitian dapat dilihat bahwa kepala sekolah sudah berhasil dalam meningkatkan kreativitas guru dalam mengajar.

\section{Pembahasan}

Kepala sekolah adalah seorang pemimpin yang memiliki wewenang terhadap bawahannya untuk meningkatkan kualitas dan mutu pendidikan, kepemimpinan kepala sekolah yang baik akan berdampak baik juga pada kemajuan serta kreativitas guru. Dalam penelitian ini peneliti sekaligus kepala sekolah melakukan upaya untuk meningkatkan kreativitas guru dalam mengajar berupa supervise akademik. Peningkatan kreativitas guru dalam mengajar adalah melalui supervisi akademik. Supervisi akademik adalah serangkaian kegiatan membantu guru mengembangkan kemampuannya mengelola proses pembelajaran untuk mencapai tujuan pembelajaran. Menurut Sudjana (2009) supervise akademik dapat meningkatkan kreativitas guru dalam mengajar, karena dengan adanya pengawasan yang dilakukan oleh kepala sekolah dapat membuat guru menjadi lebih aktif dan inovatif dalam menggunakan serta mengembangkan metodemetode pembelajaran baru, sehingga dapat mencapai keberhasilan suatu pembelajaran.

Berdasarkan dari hasil penelitian dapat dilihat bahwa upaya kepala sekolah dalam meningkatkan kreativitas guru dalam pembelajaran daring melalui supervise sudah dapat dikatakan berhasil, hal itu terbukti dari hasil penelitian bahwa kreativitas guru mengalami peningkatan setelah dilakukannya refleksi pembelajaran oleh kepala sekolah berupa supervisi akademik. Pada item kreativitas guru dalam menyusun RPP didapat nilai rata-rata sebesar 75 dengan persentase $85 \%$ pada kategori baik, pada item kreativitas menggunakan metode pembelajaran didapat nilai rata-rata sebesar 80 dengan persentase 90\% pada kategori baik, kemudian pada item inisiatif pengelolaan pembelajaran daring didapat nilai rata-rata sebesar 70 dengan 
persentase sebesar $80 \%$ pada kategori baik, dan pada item hasil belajar siswa didapat ratarata sebesar 70 dengan persentase $80 \%$ pada kategori baik. Data hasil analisis observasi aktivitas guru juga mengalami peningkatan pada setiap pertemuan, pada siklus I pertemuan pertama persentase aktivitas guru didapat sebanyak $63 \%$ pada kategori cukup baik, kemudian pada pertemuan kedua didapat persentase aktivitas guru sebesar $66 \%$ pada kategori cukup baik. Setelah pelaksanaan siklus I dilanjutkan ke siklus II aktivitas guru terjadi peningkatan pada pertemuan ketiga didapat persentase aktivitas guru sebesar $86 \%$ pada kategori baik, pada pertemuan keempat didapat persentase aktivitas guru sebesar $94 \%$ pada kategori baik.

Berdasarkan pemaparan diatas dapat disimpulkan bahwa upaya kepala sekolah dalam meningkatkan kreativitas guru berhasil dengan upaya yang dilakukan berupa pengawasan atau supervisi terhadap guru-guru yang mengajar di SDN 022 Harapan Baru. Hal tersebut juga sejalan dengan hasil penelitian yang dilakukan oleh Pidarta (2009) menyatakan bahwa penerapan supervisi terhadap guru dapat meningkatkan kreativitas serta disiplin guru dalam mengajar. Pendapat yang sama juga disampaikan oleh Mulyasa (2013) mengatakan bahwa kreativitas guru akan dapat terealisasikan dengan adanya tindakan yang dilakukan oleh kepala sekolah yang dapat berupa supervisi, pembinaan, dan pelatihan terhadap guru. Kreativitas guru dapat muncul disebabkan dengan adanya upaya dari kepala sekolah dalam menggali potensi guruguru sehingga dapat meningkatkan kemampuan dan kreativitas guru dalam pembelajaran.

\section{SIMPULAN}

Berdasarkan hasil penelitian dan pembahasan dapat ditarik kesimpulan bahwa upaya yang dilakukan oleh kepala sekolah dalam meningkatkan kreativitas guru dalam proses pembelajaran di SDN 022 Harapan Baru sudah dapat dikatakan berhasil terbukti dari hasil analisis observasi aktivitas guru dan data analisis kreativitas guru melalui supervise oleh kepala sekolah mengalami peningkatan secara keseluruhan sebesar $83.7 \%$ lebih besar dinadingkan dengan data sebelumnya dengan rata-rata keseluruhan hanya $60 \%$.

\section{SARAN}

Saran bagi guru agar dapat mengembangkan kemampuan serta menggunakan metode-metode terbaru dalam pembelajaran agar dapat mencapai tujuab utama dari pembelajaran, kemudian saran bagi peneliti selanjutnya agar dapat mengembangkan penelitian ini dengan variable lain dan menggunakan referensi-refferensi yang relevan dengan topic dari penelitian.

\section{DAFTAR PUSTAKA}

Andika. (2016). Pengaruh Kreativitas Guru dalam Pembelajaran dan Kecerdasan Emosional Siswa Terhadap Prestasi Belajar Ekonomi Siswa Pada Kelas X di SMA Negeri 89 Jakarta. Jurnal Ilmiah Econosains, 14(1), 12-30.

Aqib, Z. (2009). Menjadi Guru Profesional Berstandar Nasional. Bandung: Drama Widya.

Anas, S. (2004). Pengantar Statistik Pendidikan. Jakarta: Raja Grafindo

Barinto. (2012). Hubungan Kompetensi Guru Dan Supervisi Akademik Dengan Kinerja Guru Smp Negeri SeKecamatan Percut Sei Tuan. Jurnal Tabularasa PPS UNIMED.9(2), 201214.

Gunawan, I. (2015). Pengaruh Kepemimpinan Transformasional dan Kepuasan Kerja terhadap Perilaku Kewargaan Organisasi Guru Sekolah Dasar. Premiere Educandum, 5(1), 59-81.

Husein, L. (2017). Profesi Keguruan Menjadi Guru Professional, Yogyakarta.

Mulayasa, E. (2013). Menjadi Guru Profesional. Bandung: PT Remaja Rosdakarya. 
ISSN : 2303-1514 | E-ISSN : 2598-5949

Oktavia, Y. (2014). Usaha Kepala Sekolah Dalam Meningkatkan Kreativitas Pembelajaran Disekolah Dasar. Jurnal Administrasi Pendidikan, 2 (1), 60-70.

Priansa. (2014). Manajemen Supervisi dan Kepemimpinan Kepala Sekolah. Bandung: Alfabeta.

Purwanto, N. (2007). Ilmu Pendidikan Toerirtis dan Praktis. PT Remaja Rosdakarya Bandung.

Perdamean,T (2009). Profesionalitas Guru Perlu Daya Kreativitas. Bandung : Alfabeta.

Pidarta, M (2009). Supervisi Pendidikan Konstektual. Jakarta : Rineka Cipta.

Rivai, V. \& Mulyadi, D. (2011). Kepemimpinan dan Perilaku Organisasi. Jakarta: PT Raja Grafindo Persada.

Rusman. (2016). Model-Model Pembelajaran mengembangkan profesionalisme guru. Jakarta: PT RajaGrafindo Persada.

Syarifudin. (2011). Manajemen Pendidikan. Jakarta: Diadit Media.

Slamet, P, H. (2000). Manajemen Berbasis Sekolah. Jurnal Pendidikan dan
Kebudayaan. Jakarta: Departemen Pendidikan Nasional.

Sedarmayanti. (2010). Manajemen Sumber Daya Manusia, Reformasi Birokrasi dan Manajemen Pegawai Negri Sipil. Bandung: PT RefikaAditama.

Suharsaputra, U. (2016). Kepemimpinan Inovasi Pendidikan: Mengembangkan Spirit Enterpreneurship Menuju Learning School. Bandung: PT Refika Aditama.

Sabirin. (2012). Perencanaan Kepala Sekolah Tentang Pembelajaran. Jurnal Tabularasa PPS UNIMED, 9(1), 111128.

Suprihatiningrum. (2016). Guru Profesional: Pedoman Kinerja dan Kompetensi Guru. Jogyakarta: Ar Ruzz Media.

Sudjana N. (2009). Standar Kompetensi Pengawas Dimensi dan Indikator. Jakarta : Binamitra Publishing

Zainal, V. R., Hadad M. D., dan Ramly, M. (2014). Kepemimpinan dan Perilaku Organisasi. Jakarta: PT Rajagrafindo Persada. 